\title{
Vitrification Melter Study
}

James. A. Jones, P.E.

Published April 1995

U. S. Department of Energy Idaho Operations Office

Idaho Falls, Idaho 83401 


\section{DISCLAIMER}

Portions of this document may be illegible in electronic image products. Images are produced from the best available original document. 


\begin{abstract}
This report presents the results of a study performed to identify the most promising vitrification melter technologies that the Department of Energy (EM-50) might pursue with available funding. The primary focus was on plasma arc systems and graphite arc melters. The study was also intended to assist EM-50 in evaluating competing technologies, formulating effective technology strategy, developing focused technology development projects, and directing the work of contractors involved in vitrification melter development.
\end{abstract}

\title{
DISCLAIMER
}

\footnotetext{
This report was prepared as an account of work sponsored by an agency of the United States Government. Neither the United States Government nor any agency thereof, nor any of their employees, makes any warranty, express or implied, or assumes any legal liability or responsibility for the accuracy, completeness, or usefulness of any information, apparatus, product, or process disclosed, or represents that its use would not infringe privately owned rights. Reference herein to any specific commercial product, process, or service by trade name, trademark, manufacturer, or otherwise does not necessarily constitute or imply its endorsement, recommendation, or favoring by the United States Government or any agency thereof. The views and opinions of authors expressed herein do not necessarily state or reflect those of the United States Government or any agency thereof.
} 


\section{CONTENTS}

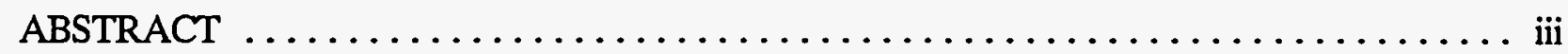

ACKNOWLEDGEMENTS $\ldots \ldots \ldots \ldots \ldots \ldots \ldots \ldots \ldots \ldots \ldots \ldots \ldots \ldots$ vii

INTRODUCTION $\ldots \ldots \ldots \ldots \ldots \ldots \ldots \ldots \ldots \ldots \ldots \ldots \ldots \ldots \ldots \ldots \ldots \ldots \ldots$

EVALUATION $\ldots \ldots \ldots \ldots \ldots \ldots \ldots \ldots \ldots \ldots \ldots \ldots \ldots \ldots \ldots \ldots \ldots \ldots$

UNRESOLVED ISSUES/PROBLEMS $\ldots \ldots \ldots \ldots \ldots \ldots \ldots \ldots \ldots \ldots \ldots \ldots \ldots$

CONCLUSIONS AND RECOMMENDATIONS $\ldots \ldots \ldots \ldots \ldots \ldots \ldots \ldots \ldots \ldots$

Appendix A-Plasma Melter Study Boundaries $\ldots \ldots \ldots \ldots \ldots \ldots \ldots \ldots \ldots \ldots \ldots \ldots$ A-1

Appendix B-Vitrification Melter Study References $\ldots \ldots \ldots \ldots \ldots \ldots \ldots \ldots \ldots \ldots$. . . . .

\section{FIGURE}

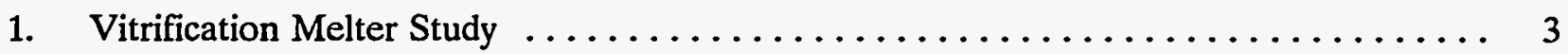




\section{ACKNOWLEDGMENTS}

The author acknowledges the contributions of the following individuals to the preparation and production of this report: William J. Quapp of LITCO; Gary Anderson of LITCO; Dr. Richard C. Eschenbach of RETECH, Inc.; John N. McFee of International Technology Corp.; Marvin Young of Aerojet General Corp.; Edward Rademacher of Mountain States Energy; Frank G. Schwartz and Yevgeny (Jenya) Macheret of DOE-ID. 


\section{VITRIFICATION MELTER STUDY \\ Final Report}

\section{INTRODUCTION}

The primary objective of this work at DOE-ID was to be able to make recommendations to EM50 on the most promising vitrification melter technology(ies) to pursue with available funding. Also, recognizing the fact that DOE will have limited personnel resources, another objective was to increase the knowledge base within DOE-ID to provide added EM-50 capability to evaluate competing technologies, formulate effective technology strategy, develop focussed technology development projects, and direct the work of contractors involved in vitrification melter development.

These objectives were accomplished by:

1. Review of technical information (studies, reports, models) currently available and being developed.

2. Identifying and evaluating what other labs, offices and commercial organizations are doing in developing vitrification melter technology.

3. Using a framework (performance, economic, risk) for evaluating and identifying the best vitrification technologies for solving current and future DOE waste problems.

4. Identifying areas where duplication or overlapping work is occurring; and deficiencies in technology where development may be needed but is not occurring.

\section{EVALUATION}

The primary objective of this study was to be able to make recommendations to EM-50 on the most promising vitrification melter technology to pursue with available funding. This began by looking at only plasma arc systems, but was enlarged to include graphite arc melters since they can also operate at high temperatures (to $1800^{\circ} \mathrm{C}$ ), produce a suitable glass-ceramic waste form, and have considerable commercial operating experience.

This study was not intended to be a thorough evaluation of the complete thermal treatment system. Other evaluators have looked at, and are continuing to look at, complete systems in greater detail than this study would allow. Various System Analysis methods and models have been used to perform evaluations, and computer models have been developed to perform different levels of evaluation. The necessary elements of any thorough analysis must be Cost, Risk, Performance and identification of Uncertainties. 
This study will draw some conclusions based on the information that was reviewed, make some recommendations on what would be an economical course to pursue to select a melter system, identify some areas where it appears information is lacking and development and testing should be performed, and provide some information for the Mixed Waste Focus Area (MWFA) to use in evaluating proposals.

\section{A. Identification of Components}

The study began with a review of available reports and other published information. Based on this review it is apparent that all thermal treatment systems have, as a minimum, the following five basic or major components:

1. Waste handling or feed system

2. Melter or containment system

3. Heat source for energy input

4. Product handling or melt extraction system

5. Off-gas processing or cleanup system

The focus of this study was intended to be primarily the heat source, with proper consideration for the requirements the heat source would place on the other components, and visa versa. The heat source was treated as a "given"or fixed feature since the objective was to look at only electric driven plasma arc or graphite arc systems. The other components that could impose requirements on the heat source, or that the heat source could impose requirements on were identified and illustrated schematically in Figure 1. These system components are also listed in a table format in Appendix A.

\section{B. Heat Source}

The objective of this study was primarily the heat source. It seems now that the heat source is the least questionable component in the system. It has been demonstrated that $\mathrm{AC}$ or DC graphite arc, or a plasma arc torch can melt any candidate waste form. The product is a glassy slag (and metal phase if wanted) that meets the TCLP.

The fixed or rotating hearth with a plasma arc torch can both handle shredded or drummed waste; however, in no case have the drums been inserted whole. There is always a cutting or melting operation as the drums are slowly inserted. The one exception to this is a test that was conducted in Switzerland on a RETECH PACT system where 4 or 5 drums of a concrete mixture were charged (pre-placed) into a cold furnace along with large chunks of concrete, the chamber was pre-heated and then the torch was started. The drums of concrete and the concrete were completely melted. This would represent a campaign basis where the furnace would run a week and then be shut down. 


\section{VITRIFICATION MELTER STUDY}

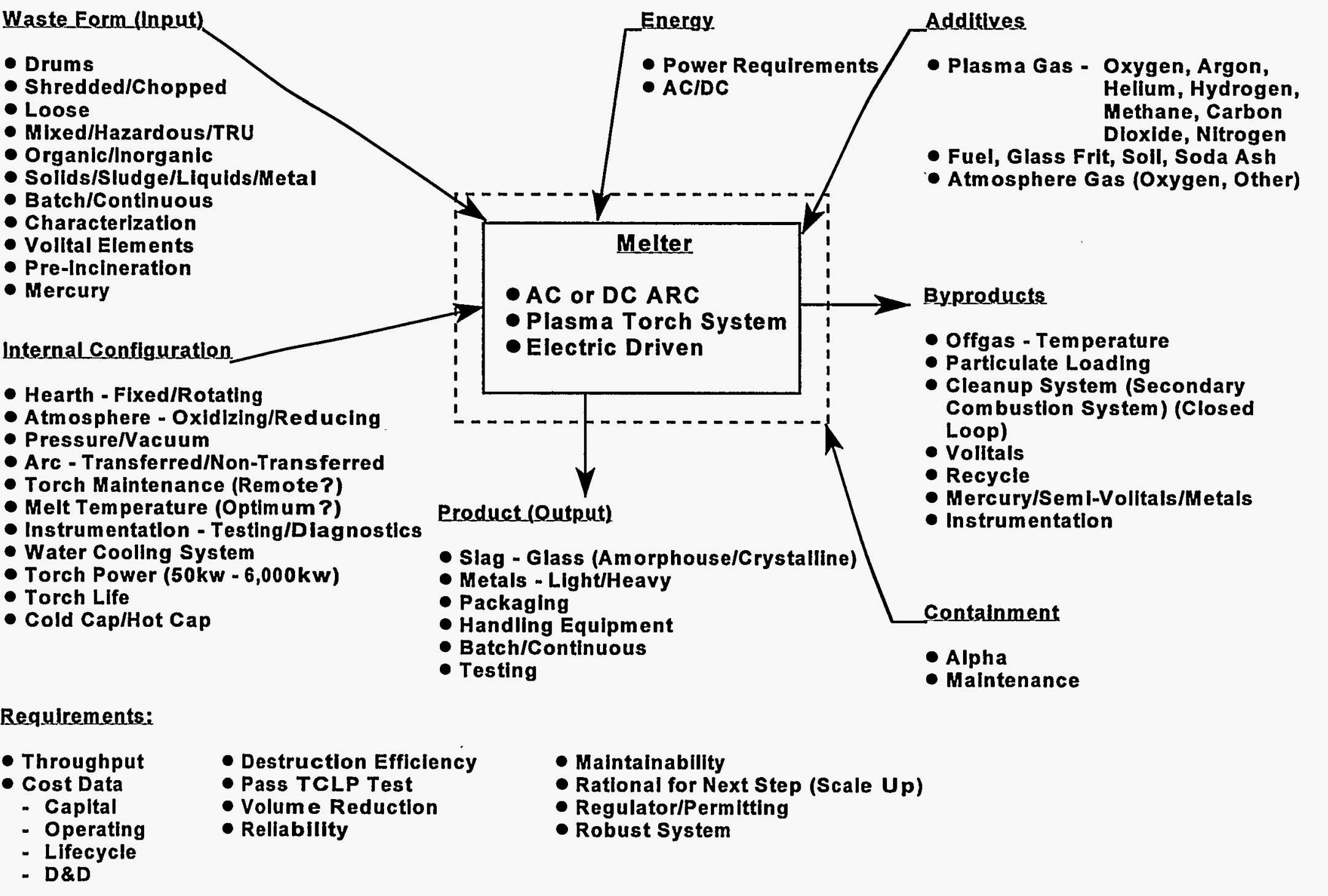

Figure 1 
In the plasma arc system, torch (electrode) life has been identified as a major concern. During testing of the RETECH centrifugal hearth system at the Mountain States Energy (MSE) facility at Butte, MT the average operating lifetime for the electrode was about 20 hours, with the shortest about 4 hours. RETECH has attributed some of the reason for the short life to operator inexperience and claims that a more realistic life expectancy for the electrode is $200-300$ hours. For maximum torch (electrode) life nitrogen should be used for the torch gas; however, in most cases it is desirable to avoid a high nitrogen atmosphere to minimize production of $\mathrm{NO}_{\mathrm{x}}$. To start the arc, helium is used for the torch gas, then nitrogen is preferred; but $\mathrm{CO}_{2}$ is a good second choice to extend the electrode life. For total recycle, chamber gas would be used for the torch gas and sacrifice some torch life. In a production facility with trained operators, electrode life could probably be expected to be toward the high end, but this is still not satisfactory for sustained operation. Commercial industry is reported to be working on a solution to the electrode life problem.

One company in particular, Aerojet General Corp.(AGC), is reported to have achieved some significant progress. Under contract with the DOE Morgantown Energy Technology Center (METC), for a twelve month program, AGC designed, fabricated, and tested six platelet-cooled electrodes for the RETECH RP-75T $(90 \mathrm{~kW})$ plasma arc torch. The testing was performed at RETECH in Ukiah, CA using a RETECH PACT-1.5 centrifugal melter. Two of the electrodes with gas injection demonstrated on the order of ten times the life of conventional water cooled electrodes. Neither electrode failed within the planned test period. The ultimate life of the of the two platelet electrodes could not be extrapolated from the test data, but their appearance is still good. Based on the observed RP-75T electrode life increase, it is reasonable to expect that the life of a 1MW platelet electrode with gas injection (the size that would be used in a melter for processing MLLW) could also be increased. The reported life of the $1 \mathrm{MW}$ electrode is approximately 200 hours, depending on operators and systems. If the same magnitude of life increase were to occur for the $1 \mathrm{MW}$ electrode as was observed for the RP-75T electrode, the $1 \mathrm{MW}$ electrode could operate without failure for approximately 2000 hours. The only method to determine the life of a $1 \mathrm{MW}$ platelet electrode would be by testing. Currently there are no plans to continue the test program.

The energy costs for the heat source are infinitesimal in the total life cycle costs and, therefore, are not a determining factor. The major questions or concerns in selecting a thermal treatment system are the other components in the system, the energy costs are a very small concern.

\section{System Components}

\section{Feed System}

The feed system is a major concern. Presently RCRA Part B requires significant detail regarding waste characterization and analysis before treatment. Since detailed data on the physical characteristics of the waste are not generally available, characterization will be very expensive. The Plasma Hearth Process (PHP) program has plans to try and convince the regulators that detailed characterization is unnecessary, and demonstrate this by processing unopened drums. Whether waste should be fed in unopened drums or shredded is a subject of debate. Both batch 
and continuous feed of the waste are being considered. The PHP and Pit-9 programs use different systems. PHP will feed whole unopened drums, while Pit-9 will shred everything. Both systems need to be field tested to determine the feasibility, advantages and problems. In the final selection, maybe both will be used depending on the particular waste to be treated.

Pre-incineration before final vitrification is recommend in some papers. This will serve as a pretreatment function for the melter to remove moisture and volitals, and organic destruction. This will result in more stable melter operation; however, this would add another step in the process that may not be worth the additional cost and complexity.

\section{Containment System}

The containment system includes everything associated with the thermal chamber except the heat source. Both the rotating and fixed hearth are being evaluated, and both have advantages and disadvantages. The service life and method of replacing the refractory lining in the fixed hearth is a concern. No method has been developed to do this remotely, and the refractory may be too radioactively hot to be replaced in a glovebox type operation. The rotating hearth does not have refractory problems (it develops a skull of slag on the walls), but there are concerns about the maintenance of the rotating mechanism. RETECH has developed a method to do the maintenance in containment (a glovebox type of operation) but it has not been demonstrated hot.

The fixed hearth can work with a cold cap, comprised of unmelted waste or additives, if the waste can be fed at a rate faster than it melts. Experimental testing has demonstrated that a cold cap will capture dust and volitals and reduce the carry-over going to the off-gas system. The rotating hearth cannot produce a cold cap unless the waste is shredded and fed with an auger. The PHP cannot produce a cold cap since the drums are drip melted into the hearth. The carbon arc melter is the only technology considered in this study that can test and demonstrate the advantages and disadvantages of operation with a cold cap.

Partitioning of radionuclides is a major question since limited testing has been done with actual radioactive waste. Testing with surrogate materials indicates that some of the radionuclides will be trapped in the refractory, and some will be carried over to the off-gas system. Large scale testing using actual radioactive material is needed to resolve this.

\section{Melt Extraction System}

The melt extraction system is the method used to get the slag and metal out of the melter. The rotating hearth has demonstrated a workable system, but still has some concerns with plugging and controlling the flow of the melt to avoid overfilling the receiving container. The fixed hearth does not have a solution yet (possible solutions may be a fixed weir and a tilt and pour system), but development and testing is continuing. PHP can have two phases in the melt, a metal and a slag phase, which can be recovered separately if desired. The Pit-9 system will oxidize most of the metal and form a fairly homogeneous slag. Only testing will demonstrate which one is technically superior. Relative cost studies may favor two phases if the metal can be used for beneficial recycle rather than processed as waste. Both are evaluating batch versus continuous operation. A satisfactory casting and handling system is still being developed. Additional testing is needed to resolve all of these issues. 


\section{Off-Gas System}

The off-gas cleanup system is probably the most uncertain of all the systems. This system provides the last barrier to prevent the release of any hazardous material to the environment; therefore, it will probably receive the most scrutiny by stakeholders and regulatory agencies. It is made up of essentially all commercial components, but there are many sequences and combinations of components being considered. A so called closed loop system with no releases is the ultimate goal, but is not technically achievable. A "controlled emissions" system may be the best obtainable. One complication is removing mercury in this system if it is not removed at the waste feed system step. R\&D efforts are continuing to investigate solutions for this problem. The instrumentation and control system for the off-gas cleanup will be very expensive. $R \& D$ efforts are continuing to develop an on-line, real time detection system to monitor emissions and divert the exhaust when any out of tolerance condition is detected. Both PHP and Pit-9 will demonstrate off-gas cleanup systems, but the details are not available at this time. Again, testing with actual radioactive waste is needed to resolve the issues.

Mountain States Energy (MSE) at Butte, MT has prepared and submitted a TTP for approval to perform additional development and testing on a "controlled emissions" off-gas system for a centrifugal hearth plasma arc torch melter. Currently they have some funding to perform system design work, and to install a slip stream test bed that is sized at a quarter scale of the existing PACT-6 melter. They are also testing some emissions monitors at Science Applications International Corporation (SAIC) that were developed at Lawrence Livermore National Laboratory (LLNL) and Mississippi State University (MSU). The goal is to develop and test online emissions monitors that would allow real time monitoring and control of the off-gas cleanup system. The system would detect any upset condition and divert the flow before any out of spec emissions are discharged from the stack. No monitor is available for dioxin, thus a grab sample must be taken and analyzed to prove destruction. However, a mass spectrometer system will be tested at the Western Environmental Technology Office (WETO) facilities in Butte, MT that may allow dioxin emission analysis. The present system utilized on the PACT-6 (wet scrubbing in combination with HEPA and carbon bed filters) is reported to remove mercury from the off-gas. Three melter systems will be available to perform the testing: a RETECH PACT-6 unit that is presently available; a small batch unit with a crucible that can be either rotated or used in a stationary mode, and utilizes a PERMA plasma torch, that is currently being commissioned for use; and a small pilot-scale melter that will use an electric based heat source (plasma, electric arc, induction heating, etc.) that is being procured.

\section{Cost, Risk, Performance Analysis}

This study looked primarily at performance; however, the selection of any thermal treatment system must include an analysis of cost and risk as well as performance.

The cost analysis must look at the life cycle or lifetime cost of the system which will include, as a minimum, the costs for development, permitting, capital, operating, disposal, and decontamination and decommissioning. 
Risk can mean many different things, but in this context it is meant to be the environmental and health risks associated with a new process, not technical or performance risk. The risk analysis would include as a minimum the risks to the workers, the public, and the environment from material handling, waste analysis and characterization, transportation, process accidents, secondary wastes, and final waste disposal.

\section{UNRESOLVED ISSUES/PROBLEMS}

There have been many studies conducted on thermal treatment systems and thousands of reports issued in the last three to four years, but there have been no conclusive recommendations on the best system to use. One reason is that each of the systems can probably be shown to be the best system for a specific waste stream. Each plasma arc system or graphite arc system has advantages in specific applications. A second reason is that there have been no tests on actual radioactive waste (excluding lab scale tests with token amounts of radioactive material). Until large scale tests are conducted with actual radioactive waste, some of the more important issues cannot be completely resolved.

From the information reviewed for this study, it appears that the principal issues or problems that need to be resolved are:

1. Characterization of Waste. - Some characterization will be required for process operability considerations. However, the regulatory requirements impose a much more stringent characterization requirement than is needed for operation. The best available information for waste characterization is waste descriptions and process knowledge. Also, certain NDE techniques such as a Radiological and Hazardous Material Measurement System (RHMMS) can be used for characterization. Any process technology that can demonstrate, through destruction efficiency and acceptability of the final waste form, that detailed characterization is not necessary will produce significant simplification and cost savings.

2. Form of Waste Feed. - This issue addresses the physical form of the LLMW, not the elemental composition. The physical form of the waste will be either bulk (such as soil), boxes, or drums. The ideal treatment system should be able to accept the waste in any physical form and change it, if necessary, by some mechanical means into a form that the melter feed system can transport into the melter. Shredding is the means that has received the most attention, but it has not been completely successful. If a decision were made that all waste (except bulk) would be pre-processed (such as shredding), and the necessary resources applied to developing a reliable process, it would greatly simplify the selection of the thermal treatment system, and be adaptable to all identified DOE LLMW. Also, this would provide the possibility of adding a mercury removal system at this step.

3. Maintenance of Melter. - Maintenance seems to fall into two categories, the fixed equipment such as the refractory lining in the fixed hearth, and the mechanical systems such as the rotating mechanism in the centrifugal hearth. Maintenance in containment (hands on in a glove box), and remote maintenance (with manipulators) are not new technologies, but they are not inexpensive. 
There are many glove box systems and remote cells in operation at many nuclear facilities. Successful application of these techniques requires that the maintenance requirements be identified at the conceptual stage, and the system designed with the appropriate maintenance technique integrated into the design from the beginning of detail design. It is a mistake to try and apply either of these techniques to a system, after the fact, that was designed for contact maintenance.

4. Torch Life. - As stated earlier, the electrode in the plasma arc torch has been identified as the weak component in that system with average operating life ranging from 20 hours up to a few hundred depending on operators and operating conditions. RETECH has demonstrated a reliable means to change out torch assemblies with a minimum down time, but it does require the process to be temporarily shut down, and it has not been demonstrated in a radioactive environment. $\mathrm{R} \& \mathrm{D}$ work on increasing electrode life is continuing with promising results. Any resources that can be applied to continuing research on extending electrode life, and demonstrating replacement in a radioactive environment will enhance the applicability of the plasma arc process.

5. Cold Cap. - The cold cap is not a component in a treatment system, but an operational concept which can substantially effect the particulate and volatile material carryover from a melter. The benefits of operating with a cold cap to reduce off-gas emissions need to be evaluated. A plasma arc melter normally does not operate with a cold cap. The configuration of the melters that will be used for PHP, Pit-9 and MSE will not allow formation of a cold cap. The graphite electrode arc melter at the U. S. Bureau of Mines (USBM) facility at Albany, OR may be the only melter the INEL is involved with that could evaluate the possible benefits of operating with a cold cap. Another possibility would be to modify one of the PHP units to work with a graphite electrode.

6. Melt Extraction. - Some form of tapping operation is required to extract the molten slag and metal from the melter when sufficient mixing and melting have occurred, and the desired viscosity have been achieved. The tapping mechanism must be able to start and stop the flow of molten material, and control the flow rate in order to deposit the molten material into a receiving container in a controlled manner. Test reports from tests on the carbon arc melter, and the fixed and centrifugal plasma arc melters have all reported some problems with the melt extraction system, some quite dramatic. Safe, reliable operation of this mechanism is essential to any melter operation; therefore, it warrants specific attention.

7. Radioactive Scrap Metal (RSM). - As stated earlier, the melter can be operated to produce a separate slag and metal phase. If a separate metal phase is produced, additional opportunities are presented for disposition of waste products. Issues that affect the decision on disposition of the RSM are: activity level, physical properties, and economics.

If the melter is operated with the objective of recovering metal, then chemistry manipulation is necessary. The melter must be operated with a reducing atmosphere, and oxygen injected directly into the melt to remove excess carbon and enhance the oxidation of radioactive components. Melt partitioning employs the use of a third agent to selectively remove unwanted species. Various fluxes or co-reactants are added to the melt to force radioactive isotopes into the slag phase. 
Based on reports of tests using surrogate materials, essentially all of the transuranic elements can be partitioned to the slag phase. Successful partitioning to less than $10 \mathrm{nCi} / \mathrm{gr}$. levels has been reported. However, there is no deminimis standard (yet) for release of RSM alloys to the scrap metal industry, so even at this low activity level there are still restrictions on how the RSM can be used. As a minimum it can be direct buried and reduce the volume of managed waste.

The main benefit of recycling is avoiding disposal costs. Without the establishment of a deminimis standard, multiple opportunities exist within the DOE complex for beneficial use of the recovered RSM such as: shield blocks, canisters, casks, disposal boxes, disposal drums, and reinforcing bar. The metal phase composition depends on the metals present in the feed stream, many elements in addition to iron will probably be present. If aluminum and copper build up in the metal, these impurities may limit future use of the metal. There can be an impact on mechanical working properties and weldability at some concentrations of impurities. Also, batch to batch variability will be a concern for any beneficial use. However, since automobiles and large appliances are recycled, there must be a tolerable concentration of impurities, or a satisfactory means of accommodating them. A new organization, The Association of Radioactive Metal Recyclers (ARMR), has been formed by 20 companies involved in recycling contaminated metals. The purpose of the organization is to foster the development of an industry focused on recycling RSM. Perhaps this organization will help to resolve some of these issues.

The quantities of DOE RSM available from LLMW for fabrication and reuse will be relatively small. Whether a single facility is used for fabrication of components for the entire DOE complex, or premiums are paid for fabrication using RSM in commercial facilities, the projected savings are highly dependent upon burial costs. Forthcoming information from ARMR may alter this position. A detailed analysis would be required to determine if beneficial reuse of RSM is economically justifiable. If the RSM from DOE could be combined with the RSM from the D\&D of commercial nuclear facilities, the economics could improve.

8. Partitioning of Radionuclides. - During thermal processing the partitioning of all toxic or otherwise potentially hazardous metals is a concern; however, the primary interest here is with the partitioning of transuranic (TRU) elements. The desired destination for all the radionuclides is the slag; however, testing with surrogate materials has shown that some of the material will be captured in the melter lining (refractory or skull), and some will go to the off-gas system as entrained feed material (dust), and volatilized feed material. It is important to be able to quantify the relative presence of both types of elemental partitioning, and understand the transport mechanism for each element. Also, the operating atmosphere of the melter (oxidizing or reducing) and any metal forming may significantly influence partitioning of TRU elements. Large scale testing with actual radioactive waste must be performed using different melter systems, preferably with a cold cap in one of the systems, to obtain the data.

9. Off-Gas System. - The basic components that make up an off-gas system are all commercially available and have extensive operating history. The issues concerning the system are instrumentation and controls, and possibly maintenance in a radioactively contaminated environment. Development of instrumentation and monitors for on-line, real time monitoring and control are continuing at places like MSE, LLNL, and MSU. Maintenance of the system has not 
received as much attention, but must be considered early in the design. This goes hand in hand with the previous issue on partitioning. The components and/or sections of the system where entrained radioactive feed material and volatilized material may settle or plate out need to be identified, and designed for maintenance in containment or remote maintenance as appropriate.

10. Scaleup and Throughput. - Testing work completed to date and near term planned testing work will all be on bench-scale, or less than full scale, systems. While these have been very successful in demonstrating a technology or proving a principal, the final test must be on a fullscale system to verify that the technology can be scaled up, and that the system will operate in a batch or continuous mode with sufficient throughput to be efficient and effective in processing the selected waste stream. Also, the full-scale system must demonstrate the successful solution to all the issues from waste feed preparation through maintenance of all parts of the system, to a fully functioning off-gas instrumentation and control system.

\section{CONCLUSIONS AND RECOMMENDATIONS}

Due to the limited time and scope of this study, it was not possible to investigate or evaluate complete systems in any great detail. As stated previously the primary objective of this study was to make recommendations on the most promising vitrification melter technology (heat source) to pursue. The comments, conclusions and recommendations are based on review of the documents listed as references in Appendix B, visits to three facilities where plasma arc systems are being developed and tested, design review meetings, and discussions with several individuals who have extensive experience in various aspects of vitrification melter technology. Based on the information obtained from these sources the following conclusions and recommendations are offered.

1. Testing with actual radioactive waste.

Perform large scale testing of all candidate systems with actual radioactive waste. This recommendation seems almost self-evident, but it cannot be over emphasized. Many of the unknowns remaining with any system that may be chosen cannot be resolved until the results of large scale testing with actual radioactive waste are available.

\section{Select a heat source (plasma arc or graphite arc).}

The best system may be different for different waste forms. On one extreme, each site could develop a vitrification system that would work well for that specific mixed waste application, but that is neither practical or economically feasible. On the other extreme, a vitrification system could be developed that would be replicated at three or four sites around the complex to process all the mixed waste. Neither extreme is being recommended, but it appears that either a plasma arc system or a graphite arc system would work over the whole range of possible options. It is recommended that both plasma arc and graphite arc systems continue to be developed on an equal basis until more test data is available that may identify one as being superior, or both may 
be carried to full scale production and applied to the specific application where each performs best.

3. Perform cost, risk, performance analysis.

Each candidate system must be evaluated by an ordered process to ensure that improvements in safety (risk), performance and cost are realized. The analysis must be performed on complete processing systems.

4. Perform a RAM (Reliability, Availability, Maintainability) analysis.

After initial selection of system components is complete, a RAM analysis should be performed. The purpose of the analysis is to model the system to verify that the proposed configuration meets the reliability and availability requirements. The analysis can be applied, in a graded approach, to the subsystems and components that present the highest risk to the operation. The reliability of a system is defined as the probability that the system will adequately perform its intended function, under normal operating conditions, for a specified mission time. Reliability is a function of both the mission length and the Mean Time To Failure (MTTF). Availability is defined as the probability that the system will be operational (available) on demand. Maintainability is the measure of the repairability of system equipment. Repairability is represented by the Mean Time To Repair (MTTR). Component MTTR values are combined with the component MTTF values to calculate availabilities.

\section{Torch life development.}

There is no reported effort being funded by DOE to increase the electrode life for the plasma arc torch. This seems to be left with the commercial torch suppliers. In recognition of the important contribution improvement in this single component could make to the increased throughput, continuity of operation, and reduced maintenance of a plasma arc system, it seems that a modest investment could pay significant dividends. There is no follow-up work planned for the apparently successful improvement reported by Aerojet General Corp. with the small scale $(90 \mathrm{~kW})$ RETECH torch. It is recommended that this development be continued to determine if the same increased electrode life can be demonstrated with a full scale (1 MW) torch.

\section{Off-gas system development.}

Development of monitors, instrumentation and controls for on line, real time analysis and control is the area needing the most R\&D support for the off-gas system. The program at MSE appears to be the most comprehensive in the complex. It is recommended that this program be supported to what ever extent is possible.

\section{Cold cap evaluation.}

The technologies under development at the INEL (PHP and Pit-9), and the systems at MSE all use a plasma torch in a configuration that will not allow evaluation of operation with a cold cap. 
The carbon arc melter at the USBM facility appears to be the only facility the INEL is programmatically involved with where operation with a cold cap can be evaluated. However, the off-gas system at the USBM facility is not the same as will be used on the plasma arc systems, so a direct comparison of operation cannot be performed. The benefits of operating with a cold cap appear to be attractive enough to warrant some programmatic change to provide a system that will allow a direct comparison. It is recommended that consideration be given to making provision in the PHP to allow operation with a carbon arc torch, in place of the plasma arc for a limited test series, so that evaluation with the same off-gas system can be performed.

\section{Systems Analysis.}

A Systems Analysis methodology should be used to perform a disciplined assessment of potential alternatives for processing or treating Mixed Low-level Waste (MLLW), and making an informed recommendation of the most promising technology or system to pursue. Several models have been developed under the MWIP that were specifically tailored for use in performing this type of analysis. Some were described at the Integrated Engineering Assessment and Evaluation Workshop conducted at Gaithersburg, MD in November 1994. It appears that EM-50 has already selected certain technologies to fund through a certain level of development and testing. Some of these may be eliminated on a technical basis as development and testing progresses. However, if it becomes necessary for the MWFA to limit the number of different technologies being pursued on a funding basis, a Systems Analysis method would be the appropriate method to make a selection.

\section{Systems Engineering}

When a decision is made to pursue a particular technology or system through engineering, design, development, testing and implementation; a Systems Engineering approach must be used to identify needs, define the system and technical requirements, ensure the necessary trade-offs are performed, and identify the products. The analysis must be performed with sufficient rigor to identify all subsystems and components necessary for operation, monitoring and control, maintenance (scheduled and unscheduled, contact and remote), and final D\&D. The type of Systems Engineering used in the aerospace industry, applied in a graded approach, would be an appropriate guide. The results of the RAM analysis, described above, would be part of the Systems Engineering analysis. The analysis should be a living document that is reviewed and updated periodically as the project progresses. 


\section{Appendix A}

Plasma Melter Study Boundaries 


\section{APPENDIX A}

\section{PLASMA MELTER STUDY BOUNDARIES}

\begin{tabular}{|c|c|c|c|c|c|c|}
\hline ENERGY & $\begin{array}{l}\text { WASTE } \\
\text { FORM } \\
\text { (INPUT) }\end{array}$ & $\begin{array}{c}\text { INTERNAL } \\
\text { CONFIGUR- } \\
\text { ATION }\end{array}$ & $\begin{array}{c}\text { PROCESS } \\
\text { ADDITIVES }\end{array}$ & $\begin{array}{l}\text { PRODUCT } \\
\text { (OUTPUT) }\end{array}$ & BYPRODUCT & REQUIREMENTS \\
\hline $\begin{array}{l}\text {-Power } \\
\text { Require- } \\
\text { ments } \\
\text {-AC/DC }\end{array}$ & $\begin{array}{l}\text {-Drums } \\
\text {-Shredded/ } \\
\text { Chopped } \\
\text {-Loose } \\
\text {-Mixed/ } \\
\text { Hazardous/ } \\
\text { TRU } \\
\text {-Organic/ } \\
\text { Inorganic } \\
\text {-Solids/ } \\
\text { Sludge/ } \\
\text { Liquid/ } \\
\text { Metal } \\
\text {-Batch / } \\
\text { Continuous } \\
\text {-Character- } \\
\text { ization } \\
\text {-Volatile } \\
\text { Elements } \\
\text {-Pre-Inciner- } \\
\text { ation } \\
\text {-Mercury }\end{array}$ & $\begin{array}{l}\text {-Hearth - } \\
\text { Fixed/ } \\
\text { Rotating } \\
\text {-Atmosphere } \\
\text { - } \\
\text { Oxidizing/ } \\
\text { Reducing } \\
\text {-Pressure / } \\
\text { Vacuum } \\
\text {-Arc- } \\
\text { Transferred/ } \\
\text { Non- } \\
\text { transferred } \\
\text {-Torch } \\
\text { Maintenance } \\
\text { (Remote?) } \\
\text {-Melt } \\
\text { Temperature } \\
\text { (Optimum?) } \\
\text {-Instrumen- } \\
\text { tation- } \\
\text { Testing / } \\
\text { Diagnostics } \\
\text {-Water } \\
\text { Cooling } \\
\text { System } \\
\text {-Torch Power } \\
\text { (50- } \\
6,000 k W \text { ) } \\
\text {-Torch Life } \\
\text {-Cold Cap }\end{array}$ & $\begin{array}{l}\text { - Plasma Gas } \\
\text { (Oxygen } \\
\text { Argon } \\
\text { Helium } \\
\text { Hydrogen } \\
\text { Methane } \\
\text { Carbon } \\
\quad \text { Dioxide } \\
\text { Nitrogen) } \\
\text { - Fuel } \\
\text { Glass Frit } \\
\text { Soil } \\
\text { Soda Ash } \\
\\
\text { - Atmosphere } \\
\text { Gas } \\
\text { (Oxygen / } \\
\text { Other) }\end{array}$ & $\begin{array}{l}\text { - Slag - } \\
\text { Glass / } \\
\text { Ceramic } \\
\text { - Metals } \\
\text { Light / } \\
\text { Heavy } \\
\text { - Packaging } \\
\text { - Handling } \\
\text { Equipment. } \\
\text { - Batch / } \\
\text { Continuous } \\
\text { - Testing }\end{array}$ & $\begin{array}{l}\text { - Off-gas - } \\
\text { Temperature } \\
\text { - Particulate } \\
\text { - Cleanup } \\
\text { System } \\
\text { (Secondary } \\
\text { Combustion } \\
\text { System) } \\
\text { (Closed } \\
\text { Loop) } \\
\text { - Volitals } \\
\\
\text { - Recycle } \\
\\
\text { - Mercury/ } \\
\text { Semi- } \\
\text { Volitals/ } \\
\text { Metals } \\
\\
\text { - Instrumen- } \\
\text { tation }\end{array}$ & $\begin{array}{l}\text { - Throughput } \\
\text { (Capacity) } \\
\text { - Cost Analysis } \\
\text { Capital } \\
\text { Operating } \\
\text { Life Cycle } \\
\text { D \& D } \\
\text { - Destruction } \\
\text { Efficiency } \\
\text { - TCLP Test } \\
\text { - Volume } \\
\text { Reduction } \\
\text { - Reliability } \\
\text { - Maintainability } \\
\text { - Scale Up Potential } \\
\text { - Regulatory / } \\
\text { Permitting }\end{array}$ \\
\hline
\end{tabular}




\section{Appendix B}

\section{Vitrification Melter Study References}


Vitrification Melter Study References

\begin{tabular}{|c|c|c|c|c|c|}
\hline Number & Title & Date & Source & Comments & Copy \\
\hline None & $\begin{array}{l}\text { Vitrification in the Plasma } \\
\text { Arc Centrifugal Treatment } \\
\text { System }\end{array}$ & $\begin{array}{l}\text { Nov } \\
93\end{array}$ & $\begin{array}{l}\text { RETECH, Inc. } \\
\text { Dr. R. C. } \\
\text { Eschenbach }\end{array}$ & $\begin{array}{l}\text { Description of the RETECH PACT } \\
\text { System. Summarizes past work and } \\
\text { future applications. }\end{array}$ & $\mathrm{Y}$ \\
\hline $\begin{array}{l}\text { EPA/625/ } \\
\text { R-92/002 }\end{array}$ & $\begin{array}{l}\text { EPA Handbook - } \\
\text { Vitrification Technologies } \\
\text { for Treatment of Hazardous } \\
\text { and Radioactive Waste }\end{array}$ & $\begin{array}{l}\text { May } \\
92\end{array}$ & EPA & $\begin{array}{l}\text { Good general background information. } \\
\text { Also, references some work that was } \\
\text { being done at other DOE sites (OR, SR, } \\
\text { RL, Rocky Flats). } \\
\text { References many studies using ISV. }\end{array}$ & $\mathrm{Y}$ \\
\hline None & $\begin{array}{l}\text { A Portable Vitrification } \\
\text { System for Waste Treatment }\end{array}$ & $\begin{array}{l}\text { Jul } \\
94\end{array}$ & $\begin{array}{l}\text { RETECH, Inc. } \\
\text { Dr. R. C. } \\
\text { Eschenbach } \\
\text { et al. }\end{array}$ & $\begin{array}{l}\text { Describes design features of the PACT } \\
-2 \text { system. }\end{array}$ & $\mathrm{Y}$ \\
\hline None & $\begin{array}{l}\text { Plasma Hearth Waste } \\
\text { Treatment Demonstration for } \\
\text { Radioactive Mixes Waste }\end{array}$ & $\begin{array}{l}\text { May } \\
94\end{array}$ & $\begin{array}{l}\text { SAIC } \\
\text { R. L. Gillins, et } \\
\text { al. }\end{array}$ & $\begin{array}{l}\text { In "Selected Papers" from SAIC. PHP } \\
\text { technology development activities } \\
\text { discussed and described. }\end{array}$ & $\mathrm{Y}$ \\
\hline
\end{tabular}


Vitrification Melter Study References

\begin{tabular}{|c|c|c|c|c|c|}
\hline Number & Title & Date & Source & Comments & Copy \\
\hline None & $\begin{array}{l}\text { Evaluation of the Plasma } \\
\text { Hearth Process for Mixed } \\
\text { Waste Treatment } \\
\text { Applications }\end{array}$ & $\begin{array}{l}\text { May } \\
94\end{array}$ & $\begin{array}{l}\text { SAIC } \\
\text { G. R. Hassel, et } \\
\text { al. }\end{array}$ & $\begin{array}{l}\text { In "Selected Papers" from SAIC. } \\
\text { Description of tests using a large-scale } \\
\text { proof of principle demonstration PHP } \\
\text { system. }\end{array}$ & $\mathrm{Y}$ \\
\hline None & $\begin{array}{l}\text { Quantum-Catalytic } \\
\text { Extraction Process } \\
\text { Application to Mixed Waste } \\
\text { Processing }\end{array}$ & 1993 & $\begin{array}{l}\text { MMT } \\
\text { C. A. Herbst, et } \\
\text { al. }\end{array}$ & $\begin{array}{l}\text { Description of Molten Metal } \\
\text { Technology's (MMT) Catalytic } \\
\text { Extraction Process. }\end{array}$ & $\mathrm{Y}$ \\
\hline $\begin{array}{l}\text { DOE/EM- } \\
0124 \mathrm{P}\end{array}$ & $\begin{array}{l}\text { Minimum Additive Waste } \\
\text { Stabilization (MAWS) }\end{array}$ & $\begin{array}{l}\text { Feb } \\
94\end{array}$ & $\begin{array}{l}\text { DOE-HQ / EM } \\
\text { OTD }\end{array}$ & $\begin{array}{l}\text { Description of the MAWS concept, } \\
\text { tests and evaluations being done, } \\
\text { organizations involved, and heat } \\
\text { sources (joule and plasma) }\end{array}$ & $Y$ \\
\hline None & $\begin{array}{l}\text { Melter System Preliminary } \\
\text { Design Technical Review } \\
\text { Meeting }\end{array}$ & $\begin{array}{l}\text { Oct } \\
94\end{array}$ & $\begin{array}{l}\text { LITCO } \\
\text { N. Kim Rogers, } \\
\text { et al. }\end{array}$ & $\begin{array}{l}\text { IWTP meeting to conduct an objective } \\
\text { evaluation of thermal treatment } \\
\text { options, and provide feedback on the } \\
\text { preliminary design so that the IWTP } \\
\text { can proceed with the next phase of } \\
\text { design. }\end{array}$ & $\mathrm{Y}$ \\
\hline
\end{tabular}


Vitrification Melter Study References

\begin{tabular}{|c|c|c|c|c|c|}
\hline Number & Title & Date & Source & Comments & Copy \\
\hline $\begin{array}{l}\text { EGG- } \\
\text { WTD- } \\
11138\end{array}$ & $\begin{array}{l}\text { Arc Melter Demonstration } \\
\text { Baseline Test Results }\end{array}$ & $\begin{array}{l}\text { Jul } \\
94\end{array}$ & $\begin{array}{l}\text { LITCO } \\
\text { N. R. Soelberg, } \\
\text { et al. }\end{array}$ & $\begin{array}{l}\text { BWID Prog. Series of pilot-scale } \\
\text { electric arc melter tests conducted on } \\
\text { five mixtures of "previously } \\
\text { incinerated" surrogate buried mixes of } \\
\text { wastes and soil for demonstrating } \\
\text { commercial electric arc furnace } \\
\text { technology. }\end{array}$ & $Y$ \\
\hline $\begin{array}{l}\text { EGG- } \\
\text { WTD- } \\
9911\end{array}$ & $\begin{array}{l}\text { Melter Development Needs } \\
\text { Assessment for RWMC } \\
\text { Buried Wastes }\end{array}$ & $\begin{array}{l}\text { Feb } \\
92\end{array}$ & $\begin{array}{l}\text { LITCO } \\
\text { A. D. } \\
\text { Donaldson, } \\
\text { et al. }\end{array}$ & $\begin{array}{l}\text { Survey and initial assessment of the } \\
\text { existing state-of-the-art melter } \\
\text { technology necessary to thermally treat } \\
\text { buried TRU waste. Surveys the state of } \\
\text { existing melter technology. }\end{array}$ & $\mathrm{Y}$ \\
\hline $\begin{array}{l}\text { EGG- } \\
\text { WTD- } \\
10981\end{array}$ & $\begin{array}{l}\text { Baseline Tests for Arc Melter } \\
\text { Vitrification of INEL Buried } \\
\text { Wastes, Volume I }\end{array}$ & $\begin{array}{l}\text { Nov } \\
93\end{array}$ & $\begin{array}{l}\text { LITCO } \\
\text { L. L. Oden, et } \\
\text { al. }\end{array}$ & $\begin{array}{l}\text { Presents results of baseline test series } \\
\text { using the electric arc melter at the } \\
\text { USBM Arc Furnace Integrated Waste } \\
\text { Processing Test Facility using five } \\
\text { different surrogate waste feed mixtures. }\end{array}$ & $\mathrm{Y}$ \\
\hline
\end{tabular}


Vitrification Melter Study References

\begin{tabular}{|c|c|c|c|c|c|}
\hline Number & Title & Date & Source & Comments & Copy \\
\hline $\begin{array}{l}\text { EGG-MS- } \\
11211 \\
\text { V1 }\end{array}$ & $\begin{array}{l}\text { Integrated Thermal } \\
\text { Treatment System Study - } \\
\text { Phase } 1 \text { Results }\end{array}$ & $\begin{array}{l}\text { Jul } \\
94\end{array}$ & $\begin{array}{l}\text { LITCO } \\
\text { W. J. Quapp, et } \\
\text { al. }\end{array}$ & $\begin{array}{l}\text { Comparison of widely varying thermal } \\
\text { treatment technologies for managing } \\
\text { MLLW. Ten different systems } \\
\text { encompassing several incineration } \\
\text { design options are studied. }\end{array}$ & $\mathrm{N}$ \\
\hline $\begin{array}{l}\text { LITCO- } \\
\text { MS- } \\
11211\end{array}$ & $\begin{array}{l}\text { Second DRAFT, Integrated } \\
\text { Thermal Treatment System } \\
\text { Study - Phase } 2 \text { Results }\end{array}$ & $\begin{array}{l}\text { Oct } \\
94\end{array}$ & $\begin{array}{l}\text { LITCO } \\
\text { F. Feizollahi } \\
\text { W. J. Quapp }\end{array}$ & $\begin{array}{l}\text { Assessment of several thermal } \\
\text { treatment alternatives, with eight types } \\
\text { of primary processing units. The types } \\
\text { evaluated are different than the ten } \\
\text { alternatives evaluated in Phase } 1 .\end{array}$ & $\mathrm{Y}$ \\
\hline None & $\begin{array}{l}\text { (ITTS Appendix B) } \\
\text { A Comparison of Melter } \\
\text { Types for Vitrification of } \\
\text { Mixed Low-Level Waste } \\
\text { Residues }\end{array}$ & $\begin{array}{l}\text { Jan } \\
95\end{array}$ & $\begin{array}{l}\text { LITCO } \\
\text { W. J. Quapp }\end{array}$ & $\begin{array}{l}\text { Provides a discussion of melter types, } \\
\text { similarities and differences. Provides } \\
\text { an overview of six different melters to } \\
\text { help understand the basic features and } \\
\text { design differences. }\end{array}$ & $\mathrm{Y}$ \\
\hline $\begin{array}{l}\text { EGG-MS- } \\
11303\end{array}$ & $\begin{array}{l}\text { Quantities and } \\
\text { Characteristics of the } \\
\text { Contact-Handled Low-Level } \\
\text { Mixed Waste Streams for the } \\
\text { DOE Complex }\end{array}$ & $\begin{array}{l}\text { Aug } \\
94\end{array}$ & $\begin{array}{l}\text { LITCO } \\
\text { T. L. Huebner, } \\
\text { et al. }\end{array}$ & $\begin{array}{l}\text { This report describes efforts to estimate } \\
\text { the DOE waste stream characteristics. }\end{array}$ & $Y$ \\
\hline
\end{tabular}


Vitrification Melter Study References

\begin{tabular}{|c|c|c|c|c|c|}
\hline Number & Title & Date & Source & Comments & Copy \\
\hline None & $\begin{array}{l}\text { New Incineration and } \\
\text { Melting Facility for } \\
\text { Treatment of Low-Level } \\
\text { Radioactive Wastes in } \\
\text { Switzerland }\end{array}$ & $\begin{array}{l}\text { May } \\
94\end{array}$ & $\begin{array}{l}\text { RETECH } \\
\text { W. Hoffelner, et } \\
\text { al. }\end{array}$ & $\begin{array}{l}\text { Summarizes the main characteristics of } \\
\text { the PLASMARC } 囚 \text { plant in Switzerland } \\
\text { for treating mixed wastes, liquids and } \\
\text { sludge. }\end{array}$ & $\mathrm{Y}$ \\
\hline None & $\begin{array}{l}\text { Evaluation of Plasma } \\
\text { Processing Alternatives }\end{array}$ & $\begin{array}{l}\text { Jan } \\
95\end{array}$ & $\begin{array}{l}\text { I T Corp. } \\
\text { J. N. McFee }\end{array}$ & $\begin{array}{l}\text { Private communication describing a } \\
\text { PHP process evaluation outline and } \\
\text { data to be included in cost, risk, and } \\
\text { performance calculations. }\end{array}$ & $\mathrm{Y}$ \\
\hline $\begin{array}{l}\text { DOE/ } \\
\text { MWIP-4 }\end{array}$ & $\begin{array}{l}\text { Technical Area Status Report } \\
\text { for Waste Destruction and } \\
\text { Stabilization }\end{array}$ & $\begin{array}{l}\text { Aug } \\
93\end{array}$ & $\begin{array}{l}\text { MWIP } \\
\text { DOE-OTD }\end{array}$ & $\begin{array}{l}\text { Report to detail responsibilities and } \\
\text { document efforts of the WD\&S TSG. } \\
\text { Identifies technology development } \\
\text { needs and makes recommendations for } \\
\text { future actions. }\end{array}$ & $\mathrm{Y}$ \\
\hline None & $\begin{array}{l}\text { Private communication from } \\
\text { MSE. }\end{array}$ & $\begin{array}{l}\text { Mar } \\
95\end{array}$ & $\begin{array}{l}\text { MSE } \\
\text { E. Rademacher }\end{array}$ & $\begin{array}{l}\text { Description of work being performed at } \\
\text { MSE on off-gas systems. }\end{array}$ & $Y$ \\
\hline
\end{tabular}




\section{Vitrification Melter Study References}

\begin{tabular}{|c|c|c|c|c|c|}
\hline Number & Title & Date & Source & Comments & Copy \\
\hline None & $\begin{array}{l}\text { DRAFT Final Report } \\
\text { Platelet-Cooled Plasma Arc } \\
\text { Torch }\end{array}$ & $\begin{array}{l}\text { Oct } \\
94\end{array}$ & $\begin{array}{l}\text { METC } \\
\text { W. Huber } \\
\text { M. Spatafore }\end{array}$ & $\begin{array}{l}\text { Report on the platelet cooled electrodes } \\
\text { designed by Aerojet General Corp. and } \\
\text { tested at RETECH on a } 75 T \text { plasma } \\
\text { arc torch. Describes tests where } \\
\text { electrode life was extended ten times } \\
\text { over the life of conventional electrodes. }\end{array}$ & $\mathrm{Y}$ \\
\hline $\begin{array}{l}\text { PCF- } \\
\text { DO26 }\end{array}$ & $\begin{array}{l}\text { Test Results From Plasma } \\
\text { Centrifugal Furnace } \\
\text { Demonstrations Under The } \\
\text { Buried Waste Integrated } \\
\text { Demonstration, Volume I }\end{array}$ & $\begin{array}{l}\text { Jul } \\
94\end{array}$ & $\begin{array}{l}\text { MSE } \\
\text { J. Ruffner, et al. }\end{array}$ & $\begin{array}{l}\text { Report presents a summary of tests } \\
\text { conducted, results and discussion, stack } \\
\text { gas emissions, waste volume reduction } \\
\text { estimate, and economic analysis of a } \\
\text { full-scale PCF unit. }\end{array}$ & $\mathrm{Y}$ \\
\hline None & $\begin{array}{l}\text { Response to Questions on the } \\
\text { MMT CEP System } \\
\text { Operation }\end{array}$ & $\begin{array}{l}\text { Jan } \\
95\end{array}$ & W. J. Quapp & $\begin{array}{l}\text { Private communication responding to } \\
\text { questions from Carl Cooley. }\end{array}$ & $\mathrm{Y}$ \\
\hline $\begin{array}{l}\text { INEL - } \\
95 / 0123\end{array}$ & $\begin{array}{l}\text { Decontamination of Metals } \\
\text { by Melt Refining/Slagging } \\
\text { An Annotated Bibliography: } \\
\text { Update on Stainless Steel } \\
\text { and Steel }\end{array}$ & $\begin{array}{l}\text { Jan } \\
95\end{array}$ & $\begin{array}{l}\text { R. E. Mizia, et } \\
\text { al. }\end{array}$ & $\begin{array}{l}\text { Presents results of a literature search } \\
\text { and annotated review covering } \\
\text { decontamination of metals used in the } \\
\text { nuclear industry. }\end{array}$ & $\mathrm{Y}$ \\
\hline
\end{tabular}

